\title{
Efektivitas Latihan Stimulasi Motorik dan Koping Adaptif Terhadap Kapasitas Fungsional Pada Pasien Pasca Stroke
}

\section{(Effectiveness of Motor Stimulation Exercises and Adaptive Coping Towards Functional Capacity on Post Stroke Patients)}

\author{
Wahyu Nasrullah*, Kelana Kusuma Dharma**, Suhaimi Fauzan*** \\ * Mahasiswa Prodi Keperawatan Fakultas Kedokteran Universitas Tanjungpura Pontianak \\ ** Dosen Poltekkes Kemenkes Pontianak \\ *** Dosen Keperawatan Fakultas Kedokteran Universitas Tanjungpura Pontianak \\ Jl. Prof. Dr. H. Hadari Nawawi, Pontianak \\ Email : nsrwahyu@gmail.com
}

\begin{abstract}
ABSTRAK
Latar Belakang: Stroke merupakan sejenis penyakit yang menyerang system saraf manusia karena terjadi kerusakan pada sel-sel saraf di otak akibat terganggunya pasokan darah ke bagian otak. Stroke memberi dampak secara fisik dan psikologis. Masalah fisik paling sering terjadi pasien pasca stroke ialah hemiparase yang dapat menurunkan kualitas hidup pasien pasca stroke. Terapi yang dapat diberikan adalah latihan stimulasi motorik dan koping adaptif. Tujuan : Mengetahui pengaruh latihan stimulasi motorik dan koping adaptif terhadap kapasitas fungsional pada pasien pasca stroke di RSUD Sultan Syarif Mohamad Alkadrie Kota Pontianak. Metode: Jenis penelitian kuantitatif dengan desain peneilitian quasy experiment dengan jenis pretest and postest control group design. Metode pengambilan sampel non probability sampling dengan teknik consecutive sampling. Sampel penelitian berjumlah 30 responden. Data diuji dengan menggunakan uji wilcoxon, dan mann whitney. Hasil: Hasil bivariat nilai kapasitas fungsional kelompok intervensi didapatkan nilai mean pre-test 52,67 dan post-test 79,33 menunjukkan bahwa ada pengaruh latihan stimulasi motorik dan koping adaptif yang signifikan $(\mathrm{p}<0,05)$, namun tidak ada perbedaan post-test nilai kapasitas fungsional antara kelompok intertvensi yang diberi latihan stimulasi motorik dan koping adaptif dengan kelompok kontrol yang diberi latihan stimulasi motorik ( $p>0,05$ ). Kesimpulan: Adanya pengaruh latihan stimulasi motorik dan koping adaptif terhadap peningkatan kapasitas fungsional pada pasien pasca stroke
\end{abstract}

Kata Kunci: Latihan stimuloasi motorik, Koping adaptif, Kapasitas fungsional 


\begin{abstract}
Background: Stroke is a type of disease that attacks the nervous system of humans because of damage to nerve cells in the brain due to disruption of blood supply to parts of the brain. Stroke has a physical and psychological impact. The most common physical problem in post-stroke patients is hemiparase which can reduce the quality of life for post stroke patients. A therapy which can be given is the motor stimulation exercises and the adaptive coping. Objective: To know the influence of motor stimulation exercises and adaptive coping towards functional capacity on post stroke patients in Sultan Syarif Mohamad Alkadrie General Hospital Pontianak Methods: Quantitative research through the quasy experiment research design of pretestposttest deisgn with control group. The method of sampling is non probability sampling with the consecutive sampling technique. The research participants are 30 respondents. The data tested with the wilcoxon test, and mann whitney test. Result: The bivariate results of the functional capacity of the intervention group found that the mean pre-test 52.67 and post-test 79.33 showed that there was a significant effect of motor stimulation and adaptive coping exercises ( $p<0.05)$, but there was no difference in post-test functional capacity values between the intervention groups were given motor stimulation exercises and adaptive coping with the control group given motor stimulation exercises ( $p>0.05$ ). Conclusion: The influence of motor stimulation and adaptive coping exercises on increasing functional capacity in post stroke patients.
\end{abstract}

Keywords: Motor stimulation exercises, Adaptive coping, Functional capacity

\section{PENDAHULUAN}

Stroke merupakan penyakit yang menjadi penyebab kematian dan kecacatan diseluruh dunia. American Heart Association / American Stroke Association (AHA/ASA) dalam Heart Disease and Stroke Statistics-2017 Updates, menyatakan bahwa di Amerika rata-rata setiap 40 detik seseorang mengalami stroke dan setiap 4 menit seseorang meninggal akibat stroke ${ }^{1}$. Tahun 2013 Prevalensi stroke di dunia berjumlah 25,7 juta orang penderita stroke (71\% disebabkan stroke iskemik), 6,5 juta orang meninggal dunia akibat stroke (51\% disebabkan stroke iskemik), 113 juta orang mengalami kecacatan karena stroke $(58 \%$ disebabkan stroke iskemik), dan 10,3 juta orang sebagai kasus baru penderita stroke $(67 \% \text { stroke iskemik })^{2}$. Stroke iskemik lebih sering terjadi dari pada stroke hemoragik. ${ }^{3}$

Riset Kesehatan Dasar menyatakan bahwa prevalensi stroke berdasarkan diagnosis tenaga kesehatan di Indonesia meningkat yang awalnya 7 per mil pada tahun 2013 menjadi 10,9 per mil berdasarkan diagnosis dokter pada tahun 2018 pada populasi lebih dari sama dengan 15 tahun $^{4}$. Kalimantan barat tercatat 5,8 per mil untuk pasien yang didiagnosis tenaga kesehatan dan 8,2 per mil yang terdiagnosis dan gejala stroke oleh tenaga kesehatan pada tahun 2013. 
Stroke memberikan dampak yang dapat mempengaruhi aktivitas seseorang, misalnya menjadikan seseorang tidak percaya diri, menurunkan produktivitas, hilangnya semangat untuk melaksanakan hobi dan masih banyak yang lainnya. Dampak yang ditimbulkan pasca stroke adalah gangguan berkomunikasi, gangguan emosi, nyeri, gangguan tidur, disfagia, kelumpuhan dan kecacatan sehingga dapat mengganggu kemampuan aktifitas sehari-hari yang menyebabkan penderita stroke mengalami depresi ${ }^{5}$.

Masalah fisik paling sering terjadi pasien pasca stroke ialah hemiparase pada ekstremitas atas dan ekstremitas bawah. Terkait masalah fisik tersebut terdapat program rehebilitasi untuk mengatasi atau mengembalikan fungsi fisik pasien pasca stroke $^{6}$.

Rehabilitasi merupakan program terapi dasar dari pemulihan pasien stroke yang mengalami gangguan fungsi gerak. Rehabilitasi pasca stroke dapat dilakukan berbagai metode seperti electrotherapy, hydrotherapy, exercise therapy. Rehabilitasi exercise therapy perlu diberikan pada pasien pasca stroke dalam meningkatkan kekuatan motorik untuk melakukan aktivitas seharihari ${ }^{7}$. Exercise therapy diharapkan dapat mengembalikan fungsi motorik pada pasien pasca stroke untuk mengoptimalkan fungsi sehingga dapat memandirikan dalam melakukan aktivitas sehari-hari. Latihan sendiri dapat menggunakan sarana bola karet sebagai intervensinya ${ }^{6}$.

Latihan dengan menstimulasi gerak pada tangan dapat berupa latihan fungsi menggenggam mengepalkan tangan rapatrapat dengan menggerakkan otot-otot untuk membantu membangkitkan kembali kendali otak terhadap otot-otot tersebut ${ }^{8}$.Teknik spherical grip dapat digunakan untuk membantu pemulihan bagian lengan atau bagian ekstremitas atas. Latihan spherical grip merupakan latihan fungsional tangan dengan cara menggenggam sebuah benda berbentuk bulat seperti bola pada telapak tangan ${ }^{9}$. Untuk memperkuat motivasi pasien melakukan latihan dalam meningkatkan kapasitas fungsional dan memandirikan pasien pasca stroke dalam aktivitas seharihari maka perlu diberikan latihan menerapkan koping adaptif pasca stroke

Dukungan koping adaptif ini mendorong pasien stroke untuk cepat adaptif terhadap stresor yang ada dan mengembalikan fungsi seoptimal mungkin pasca stroke ${ }^{10}$. Koping yang adaptif dapat mendukung percepatan dalam proses rehabilitasi baik secara fisik dan psikologi ${ }^{11}$. Strategi koping dikaitkan dengan dukungan sosial dan mempengaruhi aspek emosional. Dukungan yang diperoleh dari keluarga adalah sumber daya yang membantu pasien dalam manajemen penyakit. Faktor lain yang memengaruhi strategi koping adalah sifat kepribadian individu. Sehingga pasien pasca stroke dapat dilatih untuk menggunakan strategi koping yang efektif untuk dapat meningkatkan proses menerima konsekuensi stroke dan meningkatkan kualitas hidup ${ }^{12}$.

Penelitian yang dilakukan oleh Olviani di RSUD Ulin Banjarmasin pada tahun 2017 menunjukkan dari total 30 responden didapatkan 25 responden yang mengalami peningkatan kekuatan otot ekstremitas atas pada pasien stroke setelah diberikan latihan Range Of Motion (ROM) Spherical Grip ${ }^{13}$.

Studi pendahuluan yang dilakukan oleh peneliti di RSUD Sultan Syarif Mohamad Alkadrie Kota Pontianak dengan obeservasi dan wawancara perawat yang bertugas diruang rawat inap. Hasil wawancara yang dilakukan pada perawat, perawat mengatakan stroke termasuk 10 penyakit terbesar yang terjadi di RSUD Sultan Syarif Mohamad Alkadrie Kota Pontianak dan sebagian besar menunjukkan gejala sisa seperti hemipharase. Rehabilitasi yang selama ini dilakukan oleh pasien berupa 
fisioterapi dan pemijitan tradisional untuk menangani kelemahan yang diderita. Dari permasalahan diatas, peneliti berminat untuk melakukan penelitian dengan judul efektivitas latihan stimulasi motorik dan koping adaptif terhadap kapasitas fungsional pada pasien pasca stroke di RSUD Sultan Syarif Mohamad Alkadrie Kota Pontianak.

\section{METODE}

Penelitian ini menggunakan desain penelitian quasy experiment pre-post test design with non equivalent control group. Kelompok intervensi diberikan latihan stimulasi motorik dan koping adaptif selama 30 menit sehari, selama 10 hari. Pre-test dilakukan pada hari pertama dan post-test dilakukan pada hari kesepuluh. Kelompok kontrol hanya diberikan latihan stimulasi motorik selama 30 menit sehari, selama 10 hari. Pre-test dilakukan pada hari pertama dan post-test dilakukan pada hari kesepuluh. Sampel sebanyak 30 pasien pasca stroke diperoleh secara consecutive sampling di RSUD Sultan Syarif Mohamad Alkadrie Kota Pontianak. Kriteria inklusi dalam penelitian ini yaitu; pasien pasca stroke fase rehabilitasi, kesadaran komposmentis, tandatanda vital dalam kondisi stabil, dan mengalami hemipharase. Kriteria eksklusi pada penelitian ini yaitu; penderita stroke berat dengan disabilitas yang kompleks, penderita stroke yang memiliki gangguan kognitif yang berat, penderita stroke yang memiliki cedera pada ekstremitas. Instrumen penelitian yang digunakan berupa kuesioner barthel index untuk mengukur nilai kapasitas fungsional. Sampel dibagi menjadi dua kelompok, 15 orang kelompok intervensi dan 15 orang kelompok kontrol. Analisis statistik yang digunakan yaitu univariat dan bivariat.

\section{HASIL}

\section{Analisis Univariat}

Karakteristik responden dalam penelitian ini diketahui bahwa responden pada kelompok intervensi berdasarkan jenis kelamin laki-laki $(86,7 \%)$ dan perempuan $(13,3 \%)$. Pada kelompok kontrol berjenis kelamin laki-laki $(66,7 \%)$ dan perempuan $(33,3 \%)$. Berdasarkan usia kelompok intervensi lansia awal (53,3\%), dan lansia akhir (46,7). Kelompok kontrol lansia awal $(40 \%)$, dan lansia akhir $(60 \%)$. Berdasarkan Fase pasca stroke kelompok intervensi sub akut $(26,7 \%)$, dan kronik (73,3\%). Kelompok kontrol sub akut $(13,3 \%)$, dan kronik (86,7\%). Jenis stroke kelompok intervensi iskemik (100\%). Kelompok kontrol tipe stroke iskemik $(93,3 \%)$ dan hemoragik $(6,7 \%)$.

\section{Analisis Bivariat}

Sebelum dilakukan analisis bivariat dilakukan uji normalitas yang merupakan syarat untuk uji $\mathrm{t}$ berpasangan dan tidak berpasangan didapatkan distribusi data tidak normal dengan nilai signifikan $(\mathrm{p}<0,05)$, sehingga dapat menggunakan uji Wilcoxon dan uji Mann Whitney. Hasil Tabel 2 menunjukkan hasil uji statistik Wilcoxon pada kelompok intervensi didapatkan nilai $\mathrm{p}$ $0,002(\mathrm{p}<0,05)$ yang berarti ada pengaruh nilai kapasitas fungsional sebelum intervensi latihan stimulasi motorik dan koping adaptif dan sesudah intervensi latihan stimulasi motorik dan koping adaptif. Pada kelompok kontrol didapatkan nilai p 0,002 $(\mathrm{p}<0,05)$ yang berarti ada pengaruh nilai kapasitas fungsional sebelum dan sesudah diberikan latihan stimulasi motorik. Jadi dapat disimpulkan bahwa ada pengaruh signifikan nilai kapasitas fungsional antara pre-test dan post-test pada kedua kelompok. 
Tabel 1 Karakteristik Responden

\begin{tabular}{|c|c|c|c|c|}
\hline \multirow[t]{3}{*}{ Karakteristik } & \multicolumn{4}{|c|}{ Kelompok } \\
\hline & \multicolumn{2}{|c|}{ Intervensi } & \multicolumn{2}{|c|}{ Kontrol } \\
\hline & f & $\%$ & f & $\%$ \\
\hline 1. Jenis Kelamin & & & & \\
\hline a. Laki-Laki & 13 & 86,7 & 10 & 66,7 \\
\hline b. Perempuan & 2 & 13,3 & 5 & 33,3 \\
\hline 2. Usia & & & & \\
\hline a. Dewasa Akhir & 0 & 0 & 0 & 0 \\
\hline b. Lansia Awal & 8 & 53,3 & 6 & 40,0 \\
\hline c. Lansia Akhir & 7 & 46,7 & 9 & 60,0 \\
\hline d. Manula & 0 & 0 & 0 & 0 \\
\hline 3. Fase Pasca Stroke & & & & \\
\hline a. Akut & 0 & 0 & 0 & 0 \\
\hline b. Sub Akut & 4 & 26,7 & 2 & 13,3 \\
\hline c. Kronik & 11 & 73,3 & 13 & 86,7 \\
\hline 4. Jenis Stroke & & & & \\
\hline a. Iskemik & 15 & 100,0 & 14 & 93,3 \\
\hline b. Hemoragik & 0 & 0 & 1 & 6,7 \\
\hline
\end{tabular}

Sumber: Data Primer (2019)

Tabel 2 kapasitas fungsional sebelum dan sesudah latihan stimulasi motorik dan koping adaptif

\begin{tabular}{|c|c|c|c|c|c|c|c|}
\hline \multirow{2}{*}{$\begin{array}{l}\text { Kapasitas } \\
\text { Fungsional }\end{array}$} & \multicolumn{3}{|c|}{ Pre-Test } & \multicolumn{3}{|c|}{ Post-Test } & \multirow{2}{*}{$\begin{array}{c}P \\
\text { value }\end{array}$} \\
\hline & Mean & Min-Max & CI 95\% & Mean & Min-Max & CI 95\% & \\
\hline Intervensi & 52,67 & $40-85$ & $44,71-60,63$ & 79,33 & $65-85$ & 75,73-82.94 & 0,002 \\
\hline Kontrol & 50,67 & $40-85$ & $42,91-58,42$ & 75,00 & $50-85$ & $69,87-80.13$ & 0,002 \\
\hline
\end{tabular}

Sumber: Uji Wilcoxon (2019)

Tabel 3 Perbedaan sebelum dan sesudah latihan stimulasi motorik dan koping adaptif

\begin{tabular}{lccccccc}
\hline $\begin{array}{l}\text { Kapasitas } \\
\text { Fungsional }\end{array}$ & \multicolumn{3}{c}{ Intervensi } & & Kontrol & \multirow{2}{*}{$\begin{array}{c}\text { P } \\
\end{array}$} \\
\cline { 2 - 7 } & Mean & Min-Max & CI 95\% & Mean & Min-Max & CI 95\% & \\
\hline Pre-Test & 52,67 & $40-85$ & $44,71-60,63$ & 50,67 & $40-85$ & $42,91-58.42$ & 0,824 \\
Post-Test & 79,33 & $65-85$ & $75,73-82,94$ & 75,00 & $50-85$ & $69,87-80.13$ & 0,098
\end{tabular}

Sumber: Uji Mann Whitney (2019) 
Tabel 3 menunjukkan hasil uji statistik Mann Whitney nilai kapasitas fungsional pre-test antara kelompok intervensi dan kelompok kontrol didapatkan nilai $\mathrm{p}=0,824$ yang berarti tidak ada perbedaan nilai kapasitas fungsional pre-test antara kelompok intervensi dan kelompok kontrol ( $>>0,05)$. Nilai kapasitas fungsional post-test antara kelompok intervensi dan kelompok kontrol didapatkan nilai $\mathrm{p}=0,098$ yang berarti tidak ada perbedaan nilai kapasitas fungsional post-test antara kelompok intervensi dan kelompok kontrol $(\mathrm{p}>0,05)$. Dari tabel 3 dapat disimpulkan bahwa tidak terdapat perbedaan nilai kapasitas fungsional yang signifikan diantara kelompok intervensi dan kelompok kontrol baik pada pre-test maupun post-test.

\section{PEMBAHASAN}

Latihan stimulasi motorik merupakan salah satu metode rehabilitasi pasca stroke untuk meningkatkan kekuatan otot dan kemampuan melakukan gerakan tertentu pada ekstremitas atas. Hasil dari penelitian ini didapatkan adanya perbedaan nilai kapasitas fungsional antara pre-test dan post-test pada kelompok intervensi dan kelompok kontrol.

Joshi menyatakan bahwa kekuatan genggaman berkorelasi dengan fungsi ekstremitas atas dan stabilitas proksimal yang diberikan oleh korset bahu. Terdapat korelasi positif antara aktivitas cengkeraman tangan dan aktivitas otot rotator cuff. Aktivitas cengkraman tangan dan Kekuatan genggaman digunakan untuk menilai kapasitas fungsional keseluruhan dari ekstremitas atas. Karena fungsi tangan (kegiatan prehension) adalah bagian terpenting dari fungsi ekstremitas atas dalam kehidupan kita sehari-hari. Jadi dalam rehabilitasi ekstremitas atas, kekuatan genggaman digunakan sebagai salah satu parameter untuk memeriksa kemajuan atau efektivitas latihan yang memengaruhi fungsi ekstremitas atas dan ADL pasien stroke kronis ${ }^{14}$.

Sejalan dengan Horsley menyatakan bahwa ada korelasi antara kekuatan cengkeraman dan kekuatan otot scapular. Fungsi representatif dari tangan adalah untuk memegang sesuatu. Kekuatan jari saat memegang sesuatu dikenal sebagai kekuatan genggaman dan itu penting dalam evaluasi fungsi motorik tangan. Karena kekuatan genggaman sangat berkorelasi positif dengan kekuatan otot. kekuatan genggaman dapat digunakan untuk mengevaluasi perubahan kekuatan otot secara efektif dan ekonomis. Kekuatan genggaman telah digunakan dalam banyak penelitian karena pengukurannya yang sederhana. Kekuatan genggaman bukan hanya gaya yang dihasilkan oleh jari dan sendi pergelangan tangan, ia juga terhubung erat dengan kekuatan otot lengan bawah, dan sendi-sendi brakialis dan bahu ${ }^{15}$.

Penelitian ini sejalan dengan Hentu didapatkan peningkatan nilai kekuatan otot setelah dilakukan latihan ROM dan gerakan bola karet, di mana didapatkan nilai mean meningkat menjadi 14,93 pada kelompok intervensi dan 13,00 pada kelompok kontrol. Bola karet yang digunakan pada pada penelitian ini yaitu bola karet yang pada permukaannya bergerigi dan lentur, Hal ini membuktikan bahwa pemberian latihan ROM dan gerakan bola karet efektif dalam meningkatkan nilai kekuatan otot ${ }^{6}$.

Peningkatan kekuatan otot yang terjadi karena adanya latihan yang rutin dilakukan oleh responden yang dapat memberikan dampak pembesaran fibril otot. Maka dengan seringnya latihan pembesaran fibril otot juga semakin besar. Latihan menggenggam bola karet sendiri dapat membantu membangkitkan kembali kendali di otak serta latihan ini akan merangsang seratserat otot untuk lebih berkontraksi. 
Mekanisme latihan stimulasi motorik bola karet merupakan suatu modalitas rangsang sensorik raba halus dan tekanan pada reseptor ujung organ berkapsul pada ekstremitas. Respon yang akan disampaikan ke korteks sensorik di otak jalur sensorik melalui badan sel pada saraf C7-T1 secara langsung melalui sistem limbik. Pengolahan rangsang yang ada menimbulkan respon cepat pada saraf untuk melakukan aksi atas rangsangan tersebut. Rangsang sensorik halus dan tekanan akan diolah dalam korteks sensorik yang selanjutnya impuls disalurkan dalam korteks motorik. Impuls yang terbentuk di neuron motorik kedua pada nuclei nervi kranialis dan kornu anterius medulla spinalis berjalan melewati radiks anterior, pleksus saraf (di region servikal dan lumbosakral), serta saraf perifer dalam perjalanannya ke otot-otot rangka. Impuls dihantarkan ke sel-sel otot melalui motor end plate taut neuromuscular kemudian akan terjadi gerakan otot pada ekstremitas . Mekanisme ini disebut feedforward control sebagai respon terhadap rangsang tekanan dan sentuhan halus pada bola karet ${ }^{9}$.

Penelitian Prok menunjukkan bahwa kekuatan otot sebelum melakukan latihan menggenggam bola adalah $2-24 \mathrm{~kg}$ dengan rata-rata 10,56 dan sesudah dilakukan latihan menggenggam bola menjadi meningkat menjadi 4-29 Kg dengan rata-rata 14.06. terapi menggenggam bola perlahanlahan mendapatkan pemulihan terhadap penyakit stroke yang mereka derita hal ini menunjukkan bahwa aktivasi jaringan saraf bersifat use-dependent, semakin sering digunakan, semakin kuat dan semakin meningkat jumlah sinaps yang terbentuk ${ }^{9}$.

Dari hasil penelitian yang diperoleh peneliti berpendapat latihan stimulasi motorik yang dilakukan dapat meningkatkan kemampuan kapasitas fungsional dikarenakan proses terjadinya latihan motorik secara teratur yang mengalami hemiparase dengan merangsang pusat motorik diotak sehingga memicu aktivitas motorik normal terutama untuk pergerakan. Proses gerakan yang dilakukan juga meningkatkan masa otot dan meningkatkan sirkulasi darah yang berfungsi untuk meningkatkan kemampuan motorik.

Penelitian ini menggunakan dukungan koping yang adaptif untuk mempengaruhi pasien dalam menerima diri pasien pasca stroke terhadap kondisinya. Meningkatkan motivasi pasien untuk melakukan latihan dengan keinginan untuk cepat pulih. Koping pasca stroke berupa proses kontrol terhadap stressor atau stimulus yang dilakukan oleh pasien untuk mempertahankan integritas dirinya dan mengembalikan fungsi seoptimal mungkin pasca stroke. Mekanisme koping adaptif terhadap stimulus akan menghasilkan respon perilaku yang adaptif pasca stroke ${ }^{10}$.

Koping yang adaptif juga berdampak pada proses kesehatan pasien pasca stroke. Kesehatan pasien pasca stroke menjadi meningkat karena adanya respon penerimaan diri terhadap sakit yang diderita. Respon penerimaan diri tersebut berupa sikap realistis, pandai mengambil hikmah, dan ketabahan hati. Respon yang ditunjukkan pada fisik pasien berupa pernafasan yang stabil, terlihat lebih tenang, dan proses penyembuhan yang lebih cepat dari waktu seharusnya ${ }^{11}$. Hal ini menimbulkan harapan yang kuat dan keinginan untuk tetap melanjutkan hidup ini dengan terus menjalankan proses pengobatan dan program rehabilitasi sehingga dapat terjadi peningkatan kapasitas fungsional ${ }^{16}$.

Peneliti berpendapat bahwa latihan stimulasi motorik dan koping adaptif memiliki pengaruh termotivasinya pasien untuk menjalani rehabilitasi untuk meningkatkan kekuatan otot. Peningkatan kekuatan otot dapat meningkatkan kapasitas fungsional pasien dalam memenuhi 
kebutuhan dasar sehingga kualitas hidup akan meningkat.

Dari hasil penelitian yang diperoleh disimpulkan bahwa tidak terdapat perbedaan nilai kapasitas fungsional antara kelompok intervensi yang diberikan latihan stimulasi motorik serta dukungan koping adaptif dan kelompok kontrol yang diberikan latihan stimulasi motorik baik pada pre-test maupun post-test. Stroke meninggalkan gejala sisa yaitu hemipharase atau hemiplegi yang disebabkan oleh adanya sumbatan arteri serebral anterior dan media yang menimbulkan infrak pada area motorik korteks frontal. Hemipharase atau hemiplegia terjadi secara kontralateral, infark pada area motorik korteks sebelah kanan menyebabkan hemiplegia sebelah kiri atau sebaliknya ${ }^{17}$. Kondisi hemipharase dapat menurunkan kualitas hidup pasien pasca stroke dikarenakan sulit untuk melakukan ADL secara mandiri dan optimal. Strategi koping dikaitkan dengan dukungan sosial dan keluarga yang mempengaruhi aspek emosional. Dukungan yang diperoleh dari keluarga adalah sumber daya yang membantu pasien dalam manajemen penyakit. Faktor lain yang memengaruhi strategi koping adalah sifat kepribadian individu ${ }^{12}$.

Keterbatasan dalam penelitian ini Peneliti tidak dapat mengikuti kegiatan latihan stimulasi motorik dan koping adaptif setiap hari, peneliti mengikuti hanya di hari ke-1 dan hari ke-10. Peneliti tidak dapat mengamati setiap saat bentuk dukungan yang dibantu oleh keluarga sebagai sumber motivasi, peneliti tidak dapat menghindari dukungan keluarga dikarenakan sebagian besar responden hidup bersama keluarganya Peneliti tidak dapat mengontrol kegiatan atau aktivitas yang dapat meningkatkan kemampuan fisik yang dilakukan masingmasing responden dalam kehidupan seharihari, kagiatan tersebut seperti melakukan pemijatan tradisional, latihan bangun dari posisi tidur ke posisi duduk lalu ke posisi berdiri, latihan berjalan dengan berpengangan pada sisi yang lemah.

\section{SIMPULAN SARAN}

Berdasarkan penelitian dan pembahasan mengenai pengaruh latihan stimulasi motorik dan koping adaptif terhadap kapasitas fungsional pasien pasca stroke di wilayah kerja RSUD Sultan Syarif Mohamad Alkadrie Kota Pontianak maka dapat ditarik kesimpulan:

Karakteristik responden pasca stroke di wilayah kerja RSUD Sultan Syarif Mohamad Alkadrie Kota Pontianak berdasarkan jenis kelamin sebagian besar berjenis kelamin laki-laki sebanyak 23 responden $(76,6 \%)$, berdasarkan usia ratarata penderita stroke memasuki usia lansia, berdasarkan tipe stroke terbanyak bertipe stroke iskemik sebanyak 29 responden $(96,6 \%)$ dan berdasarkan fase pasca stroke terbanyak fase kronik 24 responden (80\%).

Tidak ada perbedaan nilai kapasitas fungsional pre-test antara kelompok intervensi dan kelompok kontrol. Adanya perbedaan nilai kapasitas fungsional pada kelompok intervensi dan kelompok kontrol sebelum dan sesudah pengukuran. Tidak ada perbedaan post-test nilai kapasitas fungsional kelompok intervensi dan kelompok kontrol. Peneliti berharap kepada penelitian selanjutnya dapat mengobservasi durasi pemberian latihan stimulasi motorik serta dukungan koping yang adaptif, fase pasca stroke, dan waktu evaluasi yang lebih panjang.

\section{REKOMENDASI}

Hasil penelitian ini dapat bermanfaat bagi rumah sakit khusunya pada klinik rehabilitasi medik yang memberikan 
pelayanan rahabilitasi pasca stroke. Hasil latihan stimulasi motorik dan dukungan koping adaptif dapat menjadi alternatif program rehabilitasi pasca stroke dalam mengembalikan fungsi motorik ektremitas.

Bagi pasien dan keluarga dapat menambah pengetahuan dan sebagai program rehabilitasi secara mandiri yang dilakukan oleh pasien dan keluarga.

\section{DAFTAR PUSTAKA}

1. Roger, V. e. Heart Disease and Stroke Statistics-2017 Update: A Report From the American Heart Association. Circulation, 2017; 135(10), 146-603.

2. Feigin, V. L. Global Burden Of Stroke. Circulation Research, 2017; 439-448. Doi: 10.1161/Circresaha.116.308413.

3. Venketasubramanian, N. B. Stroke Epidemiology in South, East, and South-East Asia: A Review. Journal Of Stroke, 2017; Vol 19 No.3. Doi: 10.5853/jos.2017.00234

4. Kemenkes. Riset Kesehatan Dasar 2018. Jakarta: Kementerian Kesehatan Republk Indonesia, 2018.

5. Lingga, L. All About Stroke: Hidup Sebelum dan Pascastroke. Jakarta: Elex Media Komputindo, 2013.

6. Hentu, A. R. Efektivitas Latihan Rom dan Bola Karet Terhadap Peningkatan Kekuatan Menggenggam dan Fungsi Menggenggam pada Pasien Stroke dI RSUD Sleman. Media Ilmu Kesehatan, 2018; 7(2), 149-155.

7. Winstein, C. J. Guidlines for Adult Stroke Rehabilitation and Recovery. Stroke Journal of The American Heart Association, 2016; 47(6), 68-169. Doi: 10.1161/STR.0000000000000098

8. Chaidir, R. Z. Pengaruh Latihan Range Of Motion pada Ekstremitas Atas dengan Bola Karet Terhadap Kekuatan Otot Pasien Stroke Non Hemoragi di
Ruang Rawat Stroke RSSN Bukittinggi Tahun 2012. 'Afiyah, 2014; 1-6.

9. Prok, W. G. Pengaruh Latihan Gerak Aktif Menggenggam Bola Pada Pasien Stroke Diukur Dengan Handgrip Dynamometer di Rehabilitasi Medik RSUP Prof. Dr. R.D Kandaou Manado 2016. e-Clinic (Eci), 2016; 71-75.

10. Dharma, K. K. Pemberdayaan Keluarga Untuk Mengoptimalkan Kualitas Hidup Pasien Paska Stroke. Yogtakarta: Deepublish, 2018.

11. Styana, Z. D. Bimbingan Rohani Islam dalam Menumbuhkan Respon Spiritual Adaptif Bagi Pasien Stroke Di Rumah Sakit Islam Jakarta Cempaka Putih. Jurnal Ilmu Dakwah, 2016; Vol. 36, No. 1, 45-69.

12. Visser, M. A. K. The relative effect of coping strategy and depression on health-related quality of life in patients in the chronic phase after stroke. Journal of Rehabilitation Medicine, 2014; 46, 514-519. Doi: 10.2340/16501977-1803

13. Olviani, Y. M. Pengaruh Latihan Range Of Motion (ROM) Aktif-Asistif (Spherical Grip) Terhadap Peningkatan Kekuatan Otot Ekstremitas Atas Pada Pasien Stroke di Ruang Rawat Inap Penyakit Syaraf (Seruni) RSUD Ulin Banjarmasin. Dinamika Kesehatan, 2017; 8(1), 250-257.

14. Joshi, S., Sathe, T . Correlation Between Grip Strength And Scapular Muscle. Internasional Journal of Advance Research, Ideas And Innovations In Technology, 2018; 4 (3),2111-2117.

15. Horsley, I. Do changes in handgrip strength correlate with shoulder rotator cuff function?. Shoulder Elbow. 2016; 8(2): 124-9. doi: 10.1177/1758573215626103

16. Omu, O. Religious Faith and SelfEfficacy Among Stroke Patients in Kuwait: health professionals' views. 
Disability and Rehabilitation, 2014; 1529-1535.

https://www.ncbi.nlm.nih.gov/pubmed 24564360

17. Price, S. A. Patofisiologi Konsep Klinis Proses-Proses Penyakit Edisi 6. Jakarta: EGC, 2012 